\title{
Willy Wonka's Narcissistic Personality in Roald Dahl's Charlie and the Chocolate Factory
}

\author{
Bovis Narendra Pratama \& G. Fajar Sasmita Aji \\ bovisnarendra@gmail.com \& fajar@usd.ac.id \\ Department of English Letters, Universitas Sanata Dharma
}

\begin{abstract}
Charlie and the Chocolate Factory by Roald Dahl is one of the most popular children's novels. This novel talks about the adventure of five children who have the opportunity to pay a visit to the most famous chocolate factory in the world, Wonka's. This study aims to reveal Wonka's personality disorder as well as the cause of the disorder. The first objective is to identify Willy Wonka's characteristics. Then, the second objective is to reveal Wonka's personality disorder and to explain the causes of the disorder.

The analysis shows that Willy Wonka is innovative, flamboyant, stubborn, arrogant, and authoritarian. He loves to be the center of attention by putting on outrageous attire. He cannot stand questions and considers them as criticisms or threat. He always brags the products he creates to his guests. Lastly, he always wants to take control of every situation, including taking control of his successor. The last four characteristics mentioned imply that Wonka has narcissistic personality disorder. There are three causes of Willy Wonka's personality disorder. The first cause is living alone for years without any direct contact with human beings. He exiles himself from the society for years; he only pays attention to himself. The second cause is constantly being media frenzy. People give so much credit to his products and gradually he thinks that he is the best for everything because the society already thinks so. The third cause is the spies who pretend to be his employees and try to steal his recipes. He becomes really devastated because of the tragedy. He fires all of his employees and chooses to never come out of the factory ever again. He has lost his trust on people, and he is too afraid to be betrayed by his workers for the second time.
\end{abstract}

Keywords: narcissistic personality disorder, Freudian psychoanalysis, Roald Dahl

\section{Introduction}

A work of literature contains some elements, such as plot and character. Roberts and Jacobs (1987: 61) mentioned that there are eleven elements of fiction; they are character, plot, structure, theme, style, point of view, dialogue, description, commentary, tone, and symbol. Despite those many aspects, character might be one of the most important elements because character, in a story, is usually the most discussed aspect by the readers. Character would undertake actions, they would experience problems, and they too would overcome the problems they face. This point leads to the benefit that a literary work offers, which is to explore the characters that are mentioned in the storyline. An author would put a character into different matters of life, so that the story would be more dynamic. For instance, a character might have anxiety when meeting a lot of people; another might have anger management issue or considers himself as the most superior person among 
others. By looking at what the character says, thinks, and acts, the readers could have an understanding about him/her. Readers can draw a conclusion about the personalities of the characters they read in the literary work.

As a matter of fact, an analysis of characters in literary works can open a link between literature and another discipline outside literature itself, one of which is psychology. Dastmard et al (2012: 9423) declared that psychology and literature have a reciprocal relation. Meaning to say, humans are driven by their psyche or unconscious in making literary works, and those works are able to nourish the humans' souls. Barry implies the relation between the world of literature and psychoanalysis.

Freudian interpretation, then, has always been of considerable interest to literary critics. The basic reason, again, is that the unconscious, like the poem, or novel, or play, cannot speak directly and explicitly but does so through images, symbols, emblems, and metaphors. Literature, too, is not involved with making direct statements about life, but with showing and expressing experience through imagery, symbolism, metaphor, and so on (2002: 102).

Charlie and the Chocolate Factory was written by British-born Norwegian author, Roald Dahl, and was firstly published in 1964. Basically, the storyline of this book tells about Charlie and his adventure along with four other children who had the opportunity to visit and explore Wonka's chocolate factory during one full day.

This focuses on Willy Wonka, who was the owner of Wonka's chocolate factory. Although Willy Wonka is not the main character of the story, his presence actually supports the main character this novel, which is Charlie. Without the presence of Wonka, Charlie would never receive a chocolate factory as described in end of the story; he would not be Willy Wonka's successor if the author did not put Wonka. Therefore, it is fair to say that Wonka's presence in Dahl's Charlie and the Chocolate Factory supports not only the main character, but also the storyline. Because of that reason the researcher intends to do a further analysis on this particular character as Wonka actually shapes the story of this novel. Roger B. Henkle points out the importance of the non-major character that is presented in the story. Henkle names the nonmajor character as the secondary character. In his book, he said, "The most obvious function of secondary characters is to populate the world of the novel (Henkle, 1977: 94)."

This book delivers a very successful and eccentric chocolatier, Willy Wonka, the best, the greatest, and the most revolutionary man in the sweets industry. He invented remarkable products ever since he started opening Wonka's chocolate factory. Everybody knew about his famous products and everybody was eager to know his secrets in making such illustrious products. Although he owned the most famous chocolate business in the world, he was just odd in person. He did not dress up like any ordinary adult men. He put on a plumcolored velvet tail coat, green trousers, and a gold-topped walking cane. He also cut any contacts with the society. He kept the iron gates in front his factory shut for years. The thing that came out of Wonka's factory was only his products. He locked himself away inside his enormous factory for the last ten years, and nobody knows why he did so. When he finally opened his factory to the five lucky children, he showed his true personality to his guests. Every single thing inside the factory was manifestation of Wonka's vision. He built marvelous things inside the factory by following his vision, such as the chocolate river, the meadow that is completely made of edible sweets, etc. He made sure that everything was approved by him because he could not abide ugliness. Wonka loved to exaggerate his achievements by continuously mentioning his products as the best, the most revolutionary, and so on. However, each time a question about his products was delivered, he became very defensive. Instead of replying the question, he attacked the person who asked by making irritating comments about him or her.

A study about someone's mind or 
behavior deals with the way in finding true identities so that one's personality can be understood more deeply, and perhaps many hidden facts would appear during the analysis as well. The researcher is eager to study the characteristics of Willy Wonka, especially because this character has "uncommon" behaviors that are presented throughout the story. To do so the researcher examines the relation between Willy Wonka's mind, behavior, and personality development. The researcher has several reasons for making Willy Wonka as the center of this research. The researcher chooses this topic in order to reveal how Willy Wonka is depicted in the book; what characteristics does he have in order to discover the events or the things that lead Willy Wonka into being a narcissistic person, and to show how his narcissistic personality develops. By doing so, then the readers of this study would have more understanding about this unique character.

Two problems are discussed in this study. The first is Wonka's characteristics that drive him into his narcissism, and the second is the causes of Willy Wonka's narcissistic personality.

\section{Freudian Psychoanalysis}

Psychoanalysis believes that human behavior is the result of their early experience. Peter Barry also describes psychoanalysis in his book. According to Barry (2002: 96), psychoanalysis is a form of therapy which aims to cure mental disorders by investigating the interaction of conscious and unconscious elements in the mind is the definition of psychoanalysis.

According to Freud, there are three mental divisions: the id, the ego, and the superego. The id is the agent which tries to only look for pleasure. He adds, "It is filled with energy reaching from the instincts, but it has no organizations, produces no collective will, but only a striving to bring about the satisfaction of instinctive needs subject to the observance of the pleasure principle (in Storr, 2001: 61)."
The second division, which is ego, can be defined as the agent who brings common sense and reasons to the mind. It functions to limit the id. The ego is that part of the mind representing consciousness. It employs secondary process: that is, reason, common sense, and the power to delay immediate responses to external stimuli or to internal instinctive promptings. It is originally derived from the id. Freud pictured the ego as a 'special organization', which is closely connected with the organs of perception, since it first develops as a result of stimuli from the external world impinging upon the senses (Storr, 2001: 61-62).

The third mental division is known as the superego. This division is actually the result of prolonged parental influence. Superego is the agent which aims to assist the ego.

As the child gradually acquires cultural and ethical ideas, his libidinal impulses undergo repression. Because of this split within the psyche, the child comes to realize that he can no longer idealize himself; that there is an ego-ideal to which his own ego does not always conform. Freud postulated an agency within the mind that devoted itself to self-observation: which watched the ego, and decided whether or not the ego was conforming to, or fell short of, the ego-ideal. This agency was what Freud later named the super-ego (Storr, 2001: 63).

In order to find out the causes of narcissistic personality disorder suffered by Willy Wonka, the researcher is going to look at Wonka's unconscious. In psychoanalysis, unconscious can be defined as the storehouse of those painful experiences and emotions, those wounds, fears, guilty desires, and unresolved conflicts we do not want to know about because we feel we will be overwhelmed by them (Tyson; 2006: 12). Tyson adds that until we find a way to know and acknowledge to ourselves the true causes of our repressed wounds, fears, guilty desires, and unresolved conflicts, we hang onto them in disguised, distorted, and selfdefeating ways (2006: 13). 
Another important point when analyzing Wonka's unconscious is finding the core issue(s) that he has. In other words, the researcher attempts to find the significant cause that makes Wonka become a person who suffers from narcissistic personality disorder. Core issue can be the reason why somebody is acting in a certain way when faced by a situation that reminds him/her with the most unpleasant experience in the past. Tyson argues that core issues define our being in fundamental ways. It stays with us throughout life and, unless effectively addressed, they determine our behavior in destructive ways of which we are usually unaware (2006: 17). From Tyson's description about core issue, the researcher concludes that core issue is an event or experience which has a tremendous impact on someone's unconscious that it becomes the main reason why someone behaves in a certain manner.

\section{Narcissistic Personality Disorder}

The term narcissistic is derived from the story of Narcissus, a Greek who fell in love with his own reflection in a pool. He could not leave his reflection and in the end died for admiring himself in the reflection. Terence Wilson et al explain that a narcissistic person is characterized by grandiose fantasies or behavior, constant need for admiration, and lack of empathy. This grandiosity is often seen in arrogant, boastful behavior, such as making unwarranted claims of achievement or intimacy with famous people (Wilson et al, 1996: 386).

Susan Nolen-Hoeksema explains further about narcissistic personality disorder. She explains that people with narcissistic personality disorder rely on their inflated self-evaluations and see dependency on others as weak and threatening. As the name implies, grandiosity is a distinguishing feature, as they are preoccupied with thoughts of their self- importance and with fantasies of power and success, and they view themselves as superior to most other people. In interpersonal relationships, they make entitled demands on others to follow their wishes, ignore or devalue the needs and wants of others, exploit others to gain power, and are arrogant and condescending (Nolen-Hoeksema, 2014: 268).

Corsini mentions five criteria of narcissistic personality disorder:

1. Inflated self-image (e.g., displays pretentious self-assurance and exaggerates achievements; is seen by others as egoistic, haughty, and arrogant).

2. Interpersonal exploitativeness (e.g., taken others for granted and uses them to enhance self and indulge desires; expects special favors without assuming reciprocal responsibilities).

3. Cognitive expansiveness (e.g., exhibits immature fantasies and an undisciplined imagination; is minimally constrained by objective reality, takes liberties with facts, and often lies to redeem selfillusions).

4. Insouciant temperament (e.g., manifests a general air of nonchalance and imperturbability; appears coolly unimpressionable or buoyantly optimistic, except when narcissistic confidence is shaken).

5. Deficient social conscience (e.g., flouts conventional rules of shared social living, viewing them as naïve or inapplicable to self; reveals a careless disregard for personal integrity and an indifference to the rights of others) (1994: 449).

\section{Willy Wonka's Character}

\section{Innovative}

Surviving in sweets industry is not a piece of cake because there are lots of competitors that might take Wonka down and Wonka is really aware of that fact. He has to create magnificent things; things that have never been made before. He has to come up with something new in order to last in that business. The demand to become successful and lasting in the industry has led Willy Wonka to become an incredibly innovative man. Wonka constantly thinks out of the box in order to create remarkable products that everyone would love. He does not only 
produce some ordinary chocolate and sweets, yet he invents some other unique products as well. The next citation shows some of Willy Wonka's creations.

"Mr. Willy Wonka can make marshmallows that taste of violets, and rich caramels that change color every ten seconds as you suck them, and little feathery sweets that melt away deliciously the moment you put them between your lips. He can make chewinggum that never loses its taste, and sugar balloons that you can blow up to enormous sizes before you pop them with a pin and gobble them up. And by a most secret method, he can make lovely blue birds' egg with black spots on them, and when you put one of these in your mouth, it gradually gets smaller and smaller until suddenly there is nothing left except a tiny little pink sugary baby bird sitting on the tip of your tongue (p.9)"

Some of Wonka's other inventions include the ice cream that would not melt even during the hottest day, the gum that could be blown as big as it can get, the everlasting Gobstoppers and the Hair Toffee. Those delicacies are not even available in the market until he launches them. The previous sentence is a clue that Wonka is the pioneer who is able to bring enhancement to the sweets business.

He needs his products to be the best and offbeat at the same time. With his findings, he brings breakthrough to the sweets industry and makes his business becomes stronger than any other sweets factories. Willy Wonka does not follow trends that has already existed, yet he sets them. Wonka understands that only making the best quality chocolate is not enough if he wants to be the best, which is why he keeps on producing extraordinary products. By being an innovative man who is able to invent great products, he knows that people all around the world would be his loyal customers. Below is another citation of Charlie Bucket's grandfather's dialogue when telling his family members about how great Willy Wonka is. "'Clever!' cried the old man. 'He's more than that! He's a magician with chocolate! He can make anything anything he wants! Isn't that a fact, my dears?' (p.8)"

\section{Flamboyant}

Willy Wonka always wants people to acknowledge his presence. One example which shows that he loves to seek for admiration or attention can be seen through the outfit that he wears at the D-day of the chocolate factory tour. He wants people to only pay attention to him. The following citation explains the outfit that Wonka wore as well as his physical appearance.

...He had a black top hat on his head. He wore a tail coat made of a beautiful plumcoloured velvet. His trousers were bottle green. His gloves were pearly grey. And in one hand he carried a fine gold-topped walking cane. Covering his chin, there was a small, neat, pointed black beard - a goatee. And his eyes - his eyes were most marvellously bright. They seemed to be sparkling and twinkling at you all the time. The whole face, in fact, was alight with fun and laughter (p.42)"

The citation above implies that Willy Wonka owns the quality of being a truly bold and gaudy figure. It is not complicated if someone wants to be the center of attention among a group of people, and it has been practiced by Wonka. Wonka wants to make people know and recognize his presence; he needs all attention to be drawn into him. That is why he puts on such over-the-top outfit. Commonly, adults would not have such attire, especially on a daily basis, yet Wonka prefers not to follow the mainstream. People can see Wonka as a flamboyant person only by looking at what he puts on his body.

Another proof which makes him loves to gain attention is by his way of speaking. According to the book, Wonka speaks in rather high tone. It is clearly stated by the author himself by saying "...His voice was high 
and fluety." When hearing something strange, people would naturally turn their heads and look for the source of that noise. In Wonka's case, it is his high and fluety voice which makes people would turn their heads to him, because most people would not use such manners when they speak.

He understands that by putting on such outrageous outfit and speaking in a certain way, his guests would put their eyes on him. He definitely attempts to make his presence recognizable, especially after no one saw him for years. Because of that reason, he wants to create a lasting first impression. In addition to that, Wonka wants his guests to acknowledge that the man they met at that day was the one and only Willy Wonka. He tries to emphasize on the point about being 'the one and only Willy Wonka,' and for that, he needs an effort to be recognizable. The citation above can also show his effort on being 'the one and only' which is by displaying an array of outrageousness.

\section{Stubborn}

During the tour in Wonka's factory, he is surrounded by five children who are highly curious; and most children usually have that same characteristic. A child would explore things around him/ her, and when it is necessary, they would directly deliver a question. Sometimes they are going to ask questions continuously until they get the answers they need. These children who come to Wonka's factory are eager to know more and more about the properties which Wonka has inside his enormous factory. These children are very curious about almost anything inside Wonka's factory because they have never seen anything like it before in their lives. Therefore, they start asking questions about the names of certain instruments and their functions, and they also ask about the reason why Willy Wonka needs certain instruments and so on.

Somehow, their questions seem to annoy Wonka. He is bothered by what they ask. Willy Wonka cannot stand their curiosity and eagerness to know about the instruments inside his factory. In fact, be becomes grumpy and easy to deliver irritating comments towards those children, especially to Veruca Salt and Mike Teavee because both of them ask the most questions among others. He simply does not care about how the kids or the parents might react when they hear his irritating words. One time, he makes a comment about Charlie's physical appearance by saying "You look like a skeleton! What's the matter? Hasn't there been anything to eat in your house lately? (p.64)" Wonka says that out loud in front of Charlie and his grandfather without any guilt. He does not know that Charlie comes from a really poor family, but still, it is not justifiable for him to make such comment. Moreover, everytime the kids start to question about things or give comments, Willy Wonka would say "There's no time to answer silly questions (p.67)." or "Don't argue my dear child, please don't argue! It's such a waste of precious time (p.70)."

Wonka considers those children's questions as criticisms and threats; that is why he often feels irritated by what they ask. It indicates that he does not want other people to go against what he thinks and what he does. Moreover, Wonka does not want to look as if he were weak by not being able to give satisfying answers to those questions. Therefore he becomes defensive each time a question is delivered. He tries to emphasize his status as the best chocolatier in the world by not wanting to take criticisms. He already feels comfortable with his accomplishments and thinks that they are better than anyone else's. Because of that reason, he cannot tolerate anybody who would dare to replace him, or at least doubt about his position as the best man in the sweets industry. Commonly, asking questions is a normal thing to do because the guests probably need more information, but Wonka does not agree with that thought. For Wonka, the children's questions are indications that the guests are having doubt of him as the best chocolatier, so he becomes very defensive and stubborn.

\section{Arrogant}

Willy Wonka is also an arrogant man. It is true that he is able to invent great things, 
but then he brags about it by showing it off to his guests. He brags to the guests again and again. The following citation represents his arrogance. "It's a stick of gum! It's a stick of the most amazing and fabulous and sensational gum in the world! (p.72)," and "This gum is my latest, my greatest, my most fascinating invention (p.73)."

Wonka surely gives emphasis on his sentences by saying "the most" or "greatest". He needs his visitors to know that he is the one and only Willy Wonka; the best man who creates the best sweets in the world. Nobody could ever replace his spot as the most revolutionary man in making sweets and chocolate. The quotation in the previous sentence proves that Wonka has an obsession over his achievements. He already knows that his products are great, but only knowing about that fact is not enough for Wonka. He feels the necessity to announce his achievements to others. Therefore, he does so; he tells everyone who comes to his factory about the fact that his products are the greatest and the best of the best.

\section{Authoritarian}

By the end of the story, Charlie is the only one left and Willy Wonka immediately realizes that he has found a successor for his factory. Then he told the lucky boy that he has won Wonka's chocolate factory. Wonka wants Charlie to take over his business as soon as he dies. He refuses to choose an adult to run his business because he knows that he would not have enough power to control an adult. With a child, it would be very different. It would be so much easier for Wonka to control a child than an adult. Instead of choosing a professional adult businessman or entrepreneur, he chooses Charlie, a loving and obedient boy from a poor family to take over his factory as soon as he retires.

Making a child to be his successor indicates that Wonka is an authoritarian. By choosing Charlie, in this matter, a child, Wonka can watch every single step that Charlie takes. Moreover, he knows the fact that Charlie is a very obedient boy who does not ask so many questions like Veruca or Mike, so that he wants to take advantage of that. Wonka believes that Charlie will do exactly what he is told to do, he would follow any instruction that is given to him, so he chooses Charlie among the other children. Though Wonka is finally able to find a successor who is going to continue his business, he wants to maintain his position in the business as the one in charge and also his superiority. The key to the previous sentence is the word 'superiority'. Wonka wants to make sure that he is still at the very top of any other people. Meaning to say, he has a plan to control Charlie. The following citation might support the notion that Wonka is a dominative person.

"I'm an old man. I'm much older than you think. I can't go on forever. I've got no children on my own, no family at all. So who is going to run the factory when I get too old to do it myself? Someone's got to keep it going - if only for the sake of the Oompa-Loompas. Mind you, there are thousands of clever men who would give anything for the chance to come in and take over from me, but I don't want that sort of person. I don't want a grown-up person at all. A grown-up won't listen to me; he won't learn. He will try to do things his own way and not mine. So I have to have a child. I want a good sensible loving child, one to whom I can tell all my most precious sweet-making secrets - while I am still alive (p.115116.)"

It is clear that Wonka is very authoritarian. He would do whatever it takes to keep his position at the very top, including hiring a child to run his business. He makes a very strong impression by saying that a grown-up will not listen to him.

The last four characteristics mentioned in above indicate that Willy Wonka, as a matter of fact, suffers from a personality disorder which is known as the narcissistic personality disorder. According to Paul Näcke, narcissism can be defined as the attitude of a person who treats his own body 
in the same way in which the body of a sexual object is ordinarily treated - who looks at it, that is to say, strokes it and fondless it till he obtains complete satisfaction through these activities (in Strachey, 1925: 4). A narcissistic person is usually obsessed over his/her own achievements, believes that he/she is too unique for anyone to understand them, and they have the tendency to exploit others. In addition to that, Corsini states five criteria to determine narcissism on someone:

\section{Inflated self-image, indicated by} exaggerating achievements.

2. Interpersonal exploitativeness, indicated by taking others for granted and using them to gain personal advantages.

3. Cognitive expansiveness, indicated by exhibiting immature fantasies.

4. Insouciant temperament, indicated by showing imperturbability except when narcissistic confidence is shaken.

5. Deficient social conscience, indicated by flouting conventional rules of shared social living and disregarding the rights of others (1994: 449).

All those criteria about narcissistic personality disorder are found within Willy Wonka. Firstly, Wonka brags about his inventions by naming them as the most fabulous, the best, and so on. He does not only do that on one occasion, but also on another occasion during the factory tour.

Secondly, although Corsini says that a person with narcissistic personality disorder usually shows imperturbability, it would not occur whenever the person's confidence is shaken. In Willy Wonka's case, he becomes very aggressive and extremely adamant as soon as two of the children (Veruca Salt and Mike Teavee) constantly deliver questions to him. He considers Mike and Veruca's curiosity as threat because he thinks that both of them have second thoughts about his achievements and inventions. It is their continuous questions that have shaken Wonka's confidence, that is why he defends himself by being extremely rude and grumpy whenever Mike or Veruca start to deliver questions. He needs to find a way to defend his confidence so that it will not fall apart. The way he defends it is by being rude, adamant, and grumpy. Basically, he wants to tell both children that everything must be done in his way and there can be no doubts about his creations for it is a rude thing to do.

Lastly, Wonka's tendency to exploit others supports the notion of him suffering from narcissistic personality disorder. It can be seen when he talks to Charlie about the difference between a child and an adult.

"I'm an old man. I'm much older than you think. I can't go on forever. I've got no children on my own, no family at all. So who is going to run the factory when I get too old to do it myself? Someone's got to keep it going - if only for the sake of the Oompa-Loompas. Mind you, there are thousands of clever men who would give anything for the chance to come in and take over from me, but I don't want that sort of person. I don't want a grown-up person at all. A grown-up won't listen to me; he won't learn. He will try to do things his own way and not mine. So I have to have a child. I want a good sensible loving child, one to whom I can tell all my most precious sweet-making secrets - while I am still alive (p.115116.)"

\section{The Causes of Willy Wonka's Narcissistic Personality}

\section{Lack of Social Life}

The first cause that implies Wonka as a person who suffers from narcissistic personality disorder is his lack of social life. Meaning to say, Willy Wonka does not have any direct contact with humans or the outside world for a long period of time; he does not do any communication with fellow human beings. Instead of having human employees, he employs the OompaLoompas, his tiny workers from the Loompaland. 
"I smuggled them over in large packing cases with holes in them, and they all got here safely. They are wonderful workers. They all speak English now. They love dancing and music. They are always making up songs (p.54)."

It is told that Wonka has been isolating himself inside the factory for about ten years. The followings are quotes from Grandpa Joe's dialogue when he explains about Wonka never coming out to public anymore.

"Months and months went by, but still the factory remained closed (p.15)."

"Nobody sees him any more. He never comes out. The only things that come out of that place are chocolates and sweets (p.16)."

During those long time of isolation he develops a thought that he only needs to take care of himself and his business, therefore, he does not feel any necessity to think about anyone else's problems. He has neither children nor family of his own. Meaning to say, Willy Wonka has been living all alone throughout his whole life. In chapter 30, Willy Wonka told Charlie "I've got no children of my own, no family at all (p.115)." The statement implies Wonka has a serious lack of social life. Also, his statement indicates that he has been overcoming every single thing by his own throughout his life. Therefore the researcher can conclude that Wonka is already used to listen and pay attention to his own. He himself becomes the priority in his life since he does not have any other person who lives with him or any other person to look after. Because of that condition, Wonka gradually develops a mindset about his position. He sees himself as the more superior figure than everyone else. He sees himself as the center of everything.

\section{Media Frenzy}

The second reason for the cause of Wonka's narcissistic personality is continuously becoming media frenzy. The society somehow has a part in making Wonka becoming a guy with narcissistic personality disorder. Wonka owns the best chocolate factory in the world, and everybody knows him. He is truly aware of the fact that his products are very successful. They always become the number one, and his customers love them. His customers adore whatever comes out of Wonka's factory. The society puts him on the spotlight. He and his products also become huge global phenomena. It is the news and people's acknowledgment of his products that actually increases his pride of himself.

Acknowledgement in this context is considered as praise by Willy Wonka. The more acknowledgment he gains, the more self-esteem he has. That supports the idea that narcissistic people rely on the praise of others to build up their self-esteem (Wilson et al, 1996: 386). Wonka is able to grow more and more self-esteem due to the fact that the media constantly puts him as the center of attention and also due to the fact that he is successful and adored by the society. Moreover, he lives by himself, so that it is so easy for him to admire himself because he only deals with his own for the last ten years. One example of people's acknowledgment can be found through Grandpa Joe's dialogue to Charlie. "Clever!' cried the old man. 'He's more than that! He's a magician with chocolate! He can make anything - anything he wants! Isn't that a fact, my dears?' (p.8)"

\section{The Spy Tragedy}

The other reason which causes Willy Wonka become anarcissistic person is the spy tragedy. It is a moment when spies who pretended to be Wonka's employees were sent to steal the secret recipes by his business competitors. The tragedy is a horrible experience for Wonka because it remarks the moment when he lose his trust on people and cut any contact with the world. Below is a quotation taken from Grandpa Joe's dialogue when he tells the spy tragedy to Charlie.

"Yes. All the other chocolate makers, you 
see, had begun to grow jealous of the wonderful sweets that Mr. Wonka was making, and they started sending in spies to steal his secret recipes. The spies took jobs in the Wonka factory, pretending that they were ordinary workers, and while they were there, each one of them found out exactly how a certain special thing was made (p.15)."

Before isolating himself Wonka used to have human employees; he hired the town people to work inside his factory. Unfortunately Wonka finds out that there are spies inside his factory. He becomes totally devastated for being afraid that his business would possibly come to an end. The following quotations explain Willy Wonka's devastation after his business competitors were able to sell their products using Wonka's recipes.

"...And Mr. Willy Wonka tore his beard and shouted, 'This is terrible! I shall be ruined! There are spies everywhere! I shall have to close the factory!' (p.15)"

"...He told all the workers that he was sorry, but they would have to go home. Then, he shut the main gates and fastened them with a chain. And suddenly, Wonka's giant chocolate factory became silent and deserted. The chimneys stopped smoking, the machines stopped whirring, and from then on, not a single chocolate or sweet was made, not a soul went in or out, and even Mr. Willy Wonka himself disappeared completely (p.15-16)."

The impact of the spy tragedy was so huge that it later became a painful memory that Wonka could not get rid of and kept inside his unconscious. According to Tyson (2006), who quotes Freud, the unconscious mostly keeps humans' painful memories and emotions that a person might not want to know because that person might be overwhelmed by them. In relation to Wonka's case, it is clear that the tragedy really shakes Wonka's mind and influences the changes in his behavior. Because the impact of the spy tragedy is extremely huge, it has enough power to alter the personality of the poor Willy Wonka. He, who was once has the willingness to interact with people becomes much closed and chose to separate himself from the society.

After the devastating spy tragedy, Wonka's unconscious directs him to isolate himself because he cannot repeat the same mistake as when he has human workers in the factory. It is proven by Wonka firing all of his employees and locking himself away from the society for about ten years (1964: 14-15). Therefore it is fair to say that the spy tragedy becomes the turning point of Willy Wonka, where he becomes narcissistic. Willy Wonka was once a man who does not have any disorder becomes a man who suffers from narcissistic personality disorder.

Tyson quotes a term which is known as core issues that can be defined as our being in fundamental ways. Core issues stay with us throughout life, and, unless effectively addressed, they determine our behavior in destructive ways of which we are usually unaware (2006: 17). The spy tragedy which Wonka been through is the core issue of why he becomes a narcissistic person because the tragedy actually determines his behavior, such as being arrogant, stubborn, and authoritarian. There is a relation between core issue, arrogance, stubbornness, authoritarian side, and narcissism. The explanation is on the following paragraph.

Wonka becomes stubborn, arrogant, and authoritarian because his unconscious tells him to act in those ways. He was once betrayed by spies, who pretended to be his employees but instead stole his recipes, and he is afraid to be betrayed again; he cannot have the same mistake for the second time.It is proven by him firing all of his employees, separating himself from the society for a very long time (1964: 14-15), and finally hiring small people called the OompaLoompas to be his workers (1964: 53). Hiring the Oompa-Loompas was the choice he made since he still needs workers to run the factory. Wonka believes that the OompaLoompas would not betray him, for they only need a better place for living and cacao 
beans. Wonka already provides a shelter for them and gives them cacao beans, so in return they would be his loyal worker (1964: 53-54). Firing his employees, separating himself, and hiring the Oompa-Loompas show that he does not want to be betrayed for the second time. He would rather be alone forever than being betrayed again. From there his unconscious directs him to be stubborn, arrogant, and authoritarian as a defense due to his fear of being betrayed.

Wonka is stubborn especially when he feels that someone is having a second thought about him or his products. It can be seen when he talks to Veruca Salt and Mike Teavee. Instead of having second thought, both of the children are only delivering questions to satisfy their curiosity about Wonka's factory. He would immediately cut the children's questions by saying "There's no time to answer silly questions (p.67)." or "Don't argue my dear child, please don't argue! It's such a waste of precious time (p.70)."

Wonka's arrogance can be seen when he continuously brags about his products by calling them the best, the most fabulous, and so on (1964: 72-73). He tries to show his achievements to his guests by bragging about them. As Corsini says, a person with narcissistic personality disorder often exaggerates his/her achievement (1994: 449), which makes Willy Wonka seem arrogant. After that, Wonka loves to be the dominant figure. Nolen- Hoeksema and Corsini state that a person with narcissistic personality disorder would have no doubt to exploit or take others for granted, and Wonka actually does that. It is proven by Wonka choosing Charlie to become his successor. He takes Charlie for granted. He knows that by making a child as his successor, he would still be able to control everything since the child would not have enough power to go against his will. Finally, the authoritarian side, stubbornness, and arrogance which he constantly implies in the way he acts, indicates that he suffers from narcissistic personality disorder resulted from the spy tragedy.
Meanwhile, in relation to psychoanalysis, it is fair to say that Wonka's id has taken over much of his state of mind. Anthony Storr said "the id is primitive, unorganized, and emotional: 'the realm of the illogical' (2001: 60)." He also adds that the main purpose of id is to gain satisfaction and pleasure. His id is too strong for the ego to handle, so Wonka continuously follows what comes through his mind without re-thinking what might be resulted from his actions. For example, he would immediately cut Mike Teavee's or Veruca Salt's questions because he feels extremely irritated by their questions.

That action is actually driven by his id, because cutting the children's questions simply gives satisfaction to him. He does have to hear the rest of the question which apparently offensive for him. Wonka's ego, the agent which brings common sense and reasons, and his superego, the agent which helps the ego, are too weak when compared to his id. It is broken because of the causes of Wonka's narcissism that the researcher has mentioned in the previous paragraphs. In his book, Storr also explains the origin of id. As indicated in Freud's description, the id is governed only by the most basic, primitive principle of mental dynamics: avoidance of 'unpleasure' caused by instinctual tension, which can only be achieved by satisfaction of instinctual needs accompanied by pleasure (2001: 61).

The quotation above shows that the id comes to live because it is driven by unpleasant experience. In relation to Wonka, his lack of social life, the media frenzy, and the core issue (the spy tragedy), was so overwhelming for his state of mind that it needs an 'escape'; a state where he could feel free and satisfied, where his desires are fulfilled. From there, his id starts to take over in order to be satisfied. However, Wonka's id has taken over for too long and through his id, he develops the characteristics that imply narcissism, such as being arrogant, flamboyant, stubborn, and authoritarian. 


\section{Conclusion}

From the analysis, the researcher has found five characteristics from Willy Wonka. Firstly, he is ostentatious. He loves to display what he owns in order to gain attention from other people. He wants his guests to acknowledge his presence; he wants to be the center of attention, which is why he puts on outrageous outfit. Apart from his physical appearance, he also has his own way of speaking, which is high and fluety. Secondly, Willy Wonka is incredibly innovative. He is able to create some amazing and remarkable products from his factory. He creates things that have never existed. Some of his products are one of a kind, because they are originally made by Wonka. Thirdly, Willy Wonka is stubborn. Wonka becomes extremely adamant, rude, sand grumpy whenever the children start asking questions about the instruments inside Wonka's factory. Fourthly, Willy Wonka is an arrogant man. Wonka loves to brag about his creations and his products to the guests. He calls them as the best, the most fabulous, and so on. He likes to exaggerate his achievement, hoping that people would be more and more amazed by him. Lastly, Willy Wonka is authoritarian. He always wants to be the dominant figure, because he loves to control people to gain personal advantages. It is proven by him choosing Charlie to be his successor. He believes that Charlie would do anything because basically a child would not have the power to fight against an adult. Wonka does that to micromanage, exploit, and take Charlie for granted. The analysis of the first problem shows that Willy Wonka suffers from narcissistic personality disorder. The hypothesis is supported by the characteristics of Willy Wonka that match with the characteristics of a narcissist. Wonka always wants to be the center of attention, he tends to exploit other to gain personal advantages, he often exaggerates what he achieves, and he tends to consider questions as threats or criticisms.

From the analysis of the second problem, there are three causes of Willy Wonka's narcissistic personality. The first cause is Willy Wonka's lack of social life. He has been isolating himself inside his factory for years. During those years he gradually develops a mindset that he only needs to take care of him and listen to him because he basically has nobody to be taken care of. From there he becomes more and more egoistic and he becomes the center of everything. He lives by himself and during those years he does not share anything with anyone, just himself. The second cause is becoming the media frenzy. The media always puts him on the spotlight. The news about him always becomes a hit. Though he never comes out the factory, he is able to know that people always talk about him, and people really acknowledge him. It is the acknowledgement that raises the pride of him. The more acknowledgements he gains, the more self-esteem he has. Unfortunately, the pride rises so far that causes him to suffer narcissistic personality disorder. The third cause is the spy tragedy. The spies pretend to be his employees, but instead they try to steal his recipe. Wonka is extremely devastated when he finds out about the spies, so he fires all of his employees and disappears from the society for years. The impact of the spy tragedy is so huge for Wonka that he could not get rid of it. Later, it becomes a painful memory. The tragedy influences the change inside Willy Wonka. $\mathrm{He}$, who was once willing to interact with human being, does not want to do that anymore. He chose to lock himself away from the society. He is afraid of being betrayed again, for he cannot repeat the same mistake again. His unconscious that directs him to do so, which is the result of the tragedy that shakes up Wonka's mind. Wonka's id takes over most of his state of mind, which is the result of the lack of social life, media frenzy, and also the spy tragedy. Being ruled by the id, then Wonka only follows what id directs him to do. As a result, Wonka develops several characteristics that imply narcissism. 


\section{References}

Barry, Peter. Beginning Theory: An Introduction to Literary and Cultural Theory. Manchester: Manchester University Press, 2002.

Baxter, Katherine B. "Combating the Influence of Black Stereotype in Children's Books". The Reading Teacher.Vol. 27. No. 6 (1974): p.541542. (www. stor.org/stable/ 20193551). November 3, 2016.

Encyclopedia Britannica. (http://www.britannica.com/topic/Sig mund-Freud-on-psychoanalysis1983319). September 9, 2015.

Corsini, Raymond J. Encyclopedia of Psychology.. Canada: John Wiley \& Sons, Inc., 1994.

Dahl, Roald. Charlie and the Chocolate Factory. New York: Alfred A. Knopf, Inc., 1964.

(http://en.bookfi.org/book/1484561,). August 29, 2015.

Dastmard, Farzaneh, Tooran Razmjoo., and Vali Salehi. "The Relationship between Psychology and Literature". (2012). (http://textroad.com/pdf/JBASR/ J.\%20Basic.\%20Appl.\%20Sci.\%20Res., \%202\%289\%299420-9423,\%202012 .pdf). August 30, 2016.

Dundes, Alan."Jokes and Covert Language Attitudes: The Curious Case of the Wide-Mouth Frog". Language in Society.Vol. 6. No. 2 (1977): p.146. (www.jstor.org/stable/4166922). November 3, 2016.

Henkle, Roger B., Reading the Novel: An Introduction to the Techniques of Interpreting Fiction. New York: Harper \& Row Publishers, Inc., 1977.

Munandar, Aris., and Bawono Sudewo. "A Study on the Characteristics of Mr. Willy Wonka that Set Up the Stages of the Golden Ticket Children in Roald Dahl's Charlie and the Chocolate Factory". Vol 2 (2013): p.45-56. (http://jurnal.ugm.ac.id/lexicon/article /view/5318). September 12, 2015.

Nolen-Hoeksema, Susan. Abnormal Psychology. New York: McGraw-Hill Education, 2014.

Post, Jerrold M., Current Concepts of the Narcissistic Personality: Implications for Political Psychology. (1993): p.99121.

(http://www.jstor.org/stable/pdf/ 3791395.pdf?_=1460615580974). April 14, 2016.

Roberts, Edgar V., and Henry E. Jacobs. Fiction: An Introduction to Reading and Writing. New Jersey: Prentice-Hall, Inc, 1987.

Storr, Anthony. Freud A Very Short Introduction. New York: Oxford University Press, 2001.

Strachey, James. "On Narcissism: An Introduction". The Standard Edition of the Complete Psychological Works of Sigmund Freud.Vol 14. (1925): p.67102.

(www.sakkyndig.com/psykologi/artvit /freud1925.pdf). September 13, 2015.

Strange, Jack Roy. Abnormal Psychology Understanding Behavior Disorders. New York: McGraw-Hill, Inc., 1965.

Tyson, Lois. Critical Theory Today. $2^{\text {nd }}$ Edition. New York: Routledge, 2006. Wellek, Rene, and Austin Warren. Theory of Literature. New York: Harcourt, Brace \& World, Inc., 1956.

Wilson, Terence., K. Daniel O’Leary., Peter E. Nathan., Lee Anna Clark. Abnormal Psychology: Integrating Perspectives. Needham Heights: Allyn \& Bacon, 1996. 